\title{
Analysis of Local Spatial Data Infrastructure to Support Volcanic Mudflow Mitigation along Putih River, Magelang Regency, Central Java Province, Indonesia
}

\author{
Afrinia Lisditya Permatasari ${ }^{1, *}$, Ika Afianita Suherningtyas ${ }^{1}$, Putu Perdana Kusuma Wiguna ${ }^{2}$ \\ ${ }^{1}$ Department of Geography Faculty of Science and Technology Universitas Amikom, Indonesia \\ Jl. Ring Road Utara, Condong Catur, Sleman, Yogyakarta 55283 \\ ${ }^{2}$ Center for Spatial Data Infrastructure Development (PPIDS) Universitas Udayana, Indonesia \\ Jl. P.B Sudirman, Denpasar, Bali, 80232 \\ *) Corresponding Author (e-mail: afrinia@amikom.ac.id)
}

Received: 15 June 2020 / Accepted: 22 July 2020 / Published: 12 August 2020

\begin{abstract}
One of the most devastating disasters in Indonesia was the Mount Merapi eruption in 2010. After the eruption there still exists the secondary hazard of volcanic mudflow, which has caused damage and casualties. Volcanic mudflow is a mixture of pyroclastic material and rainwater, meaning that in the rainy season the area along rivers becomes a high volcanic mudflow hazard, including the area along Putih River in Magelang Regency, Central Java Province. The development of Spatial Data Infrastructure (SDI) plays an important role in disaster management, especially in disaster mitigation efforts. Building an SDI which shares information on spatial conditions in the area along the Putih River could save many lives and reduce the risk from volcanic mudflow. This research was conducted employing interview surveys, field surveys and secondary data collection at government institutions. The results of the analysis have provided a geoportal prototype as an information gateway for the mitigation of volcanic mudflow along the Putih River and the reduction of disaster risk both for the government and community.
\end{abstract}

Keywords: volcanic mudflow, Spatial Data Infrastructure, Geoportal

\section{Introduction}

In Indonesia, Mount Merapi is the most active and dangerous volcano, with an eruption cycle of approximately five years. The latest eruption was in 2010, which was particularly devastating and resulted in the loss of lives, livestock and homes (Sanger \& Nurpatria, 2018). Pyroclastic deposits mixed with rainwater during periods of heavy rainfall trigger lahars (volcanic mudflows). These affect inhabited areas at considerable distances from volcanoes, even years after an eruption (Surono et al., 2012; Bignami et al., 2013; Lavigne, Thouret, Hadmoko, \& Sukatja, 2007; Capra, Coviello, Borselli, Márquez-Ramírez \& Arámbula-Mendoza, 2018).

Volcanic mudflows are applied as a general term for rapidly flowing, highlyconcentrated, poorly sorted sediment- laden mixtures of pyroclastic materials and water (other than normal stream flow) from a volcano. They are one of the most destructive phenomena resulting in deposits which are poorly sorted, massive, made up of clasts (chiefly of volcanic composition), and generally include a mud-poor matrix (Lavigne et al., 2007). When pyroclastic materials flow into river valleys they will produce mud that moves quickly, crashing into and damaging whatever it passes. Volcanic mudflow has high viscosity and is able to lift large rocks into rivers, so lava flow has high destructive power (Kusky, 2008).

During the rainy season, even many years after an eruption, many volcanic mudflows occur, causing serious damage to infrastructure including roads, bridges and sabo dams. Among the rivers located 
on the southern and south-western slopes of the Mount Merapi, Putih River has the highest number of debris flows and volcanic mudflows (Gonda, Hotta, Legono \& Santosa, 2012; De Belizal et al., 2013; Gonda, Legono, Sukatja \& Santosa, 2014). Putih River is located in a type 1 high hazard area of the Merapi volcano, which has the potential for 8.2 million $\mathrm{m}^{3}$ of pyroclastic mudflow from the total production of 130 million $\mathrm{m}^{3}$. The incidence of volcanic mudflow in Putih River, has been recorded 30 times, resulting in damage to 678 houses, with the potential for further damage in the next rainy seasons (BNPB, 2011; Kusumawardani, Kurniadhi, Mukhlisin \& Legono, 2017). Table 1 shows the volume of pyroclastic deposits in the region (Kusumawardani, Kurniadhi, Mukhlisin \& Legono, 2017).

Table 1. Pyroclastic Deposits from Mount Merapi.

\begin{tabular}{clcl}
\hline No & \multicolumn{1}{c}{ River } & Volume & Unit \\
\hline 1 & Gendol River & 24 & Mil. $\mathrm{m}^{3}$ \\
2 & Pabelan River & 20.8 & Mil. $\mathrm{m}^{3}$ \\
3 & Krasak River & 10.8 & Mil. $\mathrm{m}^{3}$ \\
4 & Putih River & 8.2 & Mil. $\mathrm{m}^{3}$ \\
5 & Woro River & 7.3 & Mil. $\mathrm{m}^{3}$ \\
6 & Senowo River & 4.4 & Mil. $\mathrm{m}^{3}$ \\
7 & Trising River & 3.8 & Mil. $\mathrm{m}^{3}$ \\
8 & Kuning River & 3.7 & Mil. $\mathrm{m}^{3}$ \\
9 & Boyong River & 2.4 & Mil. $\mathrm{m}^{3}$ \\
10 & Lamat River & 1.4 & Mil. $^{3}$ \\
\hline
\end{tabular}

Government and community readiness to avoid or respond to disasters appropriately and effectively is needed. One method for volcanic mudflow disaster mitigation is by using Spatial Data Infrastructure (SDI) and Geographic Information System (GIS) applications. SDI is able to share data and spatial information related to disasters (Tomas et al., 2015); for example, volcanic mudflow hazard zones, volcanic mudflow characteristics and related information. It is a political and institutional policy technology framework to facilitate the availability of spatial data, access, and utilisation of the data (Kumar \& Shekhar, 2014). SDI can also be interpreted as a system for managing spatial data (Kotsev, Minghini, Tomas, Vlado Cetl \& Lutz, 2020). Its development plays an important role in disaster mitigation efforts (Batuk, Şengezer \& Emem, 2008; Sterlacchini, Bordogna, Cappellini \& Voltolina, 2018). Development of an SDI to share information and spatial conditions of areas along Putih River could save many lives and reduce the risk from volcanic mudflows. Therefore, it is necessary to conduct research on the development of a local SDI to support volcanic mudflow mitigation along Putih River, Magelang Regency, Central Java Province, Indonesia.

\section{Research Method}

The research was conducted on the Putih River, Magelang Regency, Central Java Province, Indonesia. The geographical situation of the river is located in the physiographic unit of Mount Merapi. The location was chosen because Putih River is one of the rivers whose source is at the top of Mount Merapi and is a hazard area for volcanic mudflow.

A qualitative research method was employed. This type of research is conducted by examining the perspectives of participants (respondents or informants) with strategies that are interactive and flexible. In this case, the data collection techniques comprised interviews, field surveys and secondary data collection, such as from health service posts and gathering points, to support the development of the geoportal. Figure 1 shows the research diagram.

There were three stages of data collection in the study. The first involved interviewing officials or agencies of the local government institutions of Magelang Regency to obtain information about volcanic mudflow mitigation efforts in Kali Putih, Magelang Regency. The local institutions related to disaster mitigation are the Regional Disaster Management Agency (BPBD), Planning Agency (Bappeda), Public Works, Settlement and Housing Agency (Dinas PUPR Perkim), Balai Sabo, Health Agency and Agency for Investigation and Development of Geological Disaster Technology (BPPTKG). The second stage was the collection of secondary 
data in the form of reports and documents related to SDI, together with spatial data availability related to volcanic mudflow mitigation. The final stage was to build a geoportal prototype to share information related to the volcanic mudflow mitigation efforts.

The design of the volcanic mudflow mitigation geoportal was made using an open source platform with a basemap from OpenStreet Map and library from LeafletJS. OpenStreet Map (OSM) is a provider of world maps that can be edited without charge and can be used as alternative provider for location-based data (Qureshi \& Rai, 2020). Using OSM as a basemap provides users and developers with spatial distribution that strongly supports a geoportal. LeafletJS is an open source JavaScript library that is widely used to build web mapping applications. It supports most mobile and desktop platforms, supports HTML5 and CSS3 and is used by many web mapping site applications (Edler \& Vetter, 2019).

The final phase was to conduct system testing by employing usability testing to measure user satisfaction also to enhance the convenience and presentational delight of the geoportal system (Swaid \& Suid, 2017; Mahyavanshi, Patil \& Kulkarni, 2017). Tasks were given to 20 respondents who were living alongside Putih River. After completing these tasks, they were asked to answer questions related to usability testing on scale from 1 to 5 . The tasks are listed in Table 2 and the usability testing questions in Table 3 . Table 4 shows the category of values based on the percentage calculation results from the usability scores.

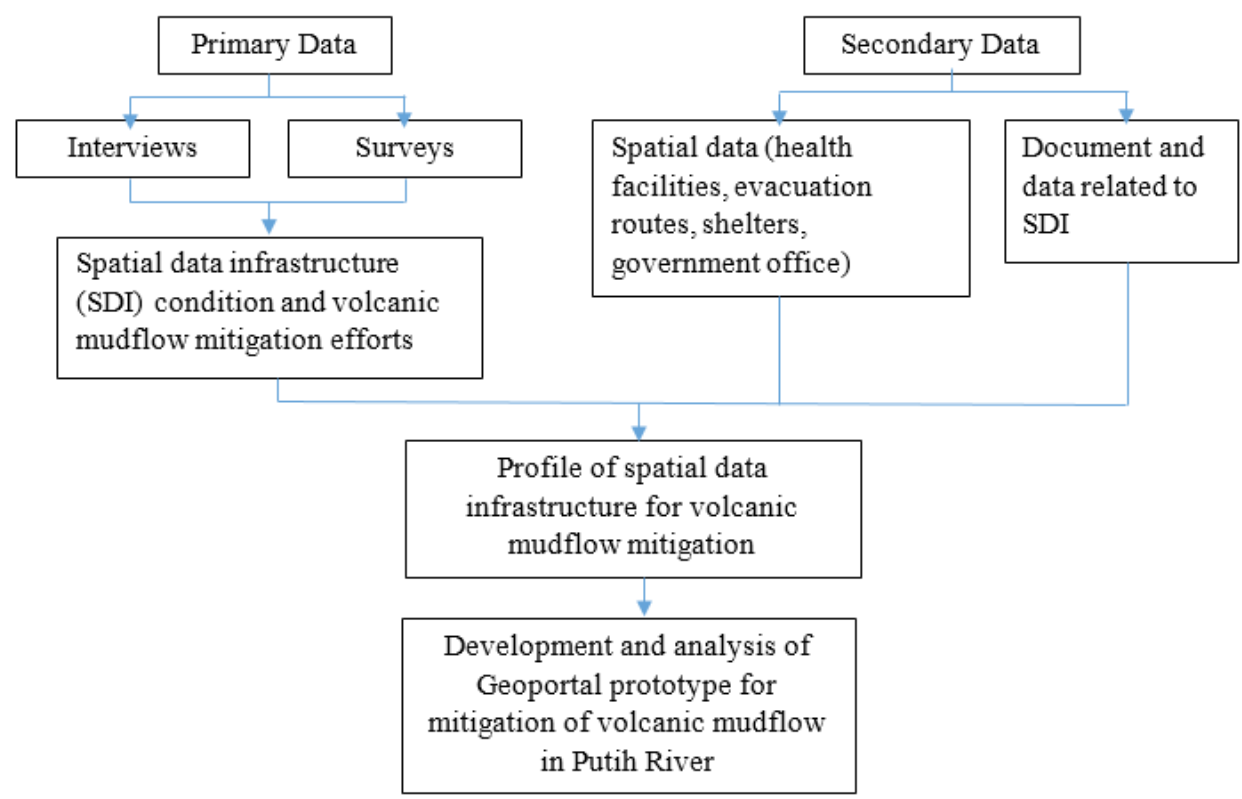

Figure 1. Research Diagram.

Table 2. Usability Testing Tasks

\begin{aligned} & \hline No \\ & \hline 1 Display the main page and map, choose map, download data \\ & 2 $\begin{array}{l}\text { Display and select an evacuation point, choose an evacuation route, navigate to the } \\ \text { evacuation location }\end{array} \\ & 3$ Choose a legend, zoom and scroll on the map \\ & \hline\end{aligned}


Table 3. Usability Testing Questions

\begin{tabular}{|c|c|c|c|c|c|c|}
\hline \multirow{2}{*}{ No. } & \multirow{2}{*}{ Question } & \multicolumn{5}{|c|}{ Usability Score } \\
\hline & & 1 & 2 & 3 & 4 & 5 \\
\hline \multicolumn{7}{|c|}{ Display } \\
\hline 1 & $\begin{array}{l}\text { Is the display on the system easy to } \\
\text { understand? }\end{array}$ & & & & & \\
\hline 2 & $\begin{array}{l}\text { Are the colours, layout, and text on the } \\
\text { system easy to see and interesting? }\end{array}$ & & & & & \\
\hline 3 & $\begin{array}{l}\text { Are the image symbols in the system } \\
\text { easy to understand? }\end{array}$ & & & & & \\
\hline \multicolumn{7}{|c|}{ Navigation } \\
\hline 4 & $\begin{array}{l}\text { Are the pages on the system easy to } \\
\text { navigate? }\end{array}$ & & & & & \\
\hline 5 & Is the system easy to read? & & & & & \\
\hline 6 & $\begin{array}{l}\text { Is the menu and appearance on the } \\
\text { system easy to remember? }\end{array}$ & & & & & \\
\hline 7 & $\begin{array}{l}\text { Are the features on the system easy to } \\
\text { operate? }\end{array}$ & & & & & \\
\hline \multicolumn{7}{|c|}{ Information } \\
\hline 8 & $\begin{array}{l}\text { Is the information on the system easy to } \\
\text { understand? }\end{array}$ & & & & & \\
\hline 9 & $\begin{array}{l}\text { Do the specifications on the system suit } \\
\text { your needs? }\end{array}$ & & & & & \\
\hline 10 & Are the data easily downloaded? & & & & & \\
\hline
\end{tabular}

Table 4. Percentage Score Category

\begin{tabular}{cl}
\hline Percentage & \multicolumn{1}{c}{ Category } \\
\hline $80 \%-100 \%$ & Very Good \\
$60 \%-79.99 \%$ & Good \\
$40 \%-59.99 \%$ & Moderate \\
$20 \%-39.99 \%$ & Less Good \\
$0 \%-19.99 \%$ & Bad \\
\hline
\end{tabular}

\section{Results and Discussion}

\subsection{Profile of Spatial Data Infrastructure in} Magelang Regency

SDI has five core components, namely data, standards, policies, access networks, and human resource (Tripathi, Agrawal \& Gupta, 2020). Based on the results of the interviews at the government agencies, as a whole the Magelang Regency government was not fully prepared for implementation of SDI to support volcanic mudflow mitigation. Overall, only the Regional Disaster Mitigation Agency (BPBD) as data provider and source of data for other agencies for the mitigation of volcanic mudflow.
The data related to disasters are provided by the BPBD of Magelang Regency and are available in ESRI Shapefile with the UTM coordinate system. The available data related to volcanic mudflow mitigation are Putih river data, evacuation routes, shelter locations and health facilities (see Table 4). Data availability is relatively complete, but overall there is a lack of information on the attribute data and missing metadata. Metadata play an important role in documenting spatial data so that the process of data transfer and exchange between systems and institutions can take place and errors due to the lack of data explanation can be minimised. 
Related to data standards, Magelang Regency follows the national standards from the Geospatial Information Agency (BIG) of Indonesia. However, the updating process of the data, especially updates on volcanic mudflows, is not specifically explained. Data acquisition for volcanic mudflow is by data transfer and exchange with BBWS Serayu Opak and BPPTKG using a flashdisk external hard disk drive.

$\mathrm{BPBD}$, as the coordinator of the mitigation of volcanic mudflow before, during and after disasters, together with BPPTKG and BBWS Serayu Opak, does not have any specific job description or detailed information, specifically regarding volcanic mudflow disasters. There are no policies or decrees from Magelang
Regency related to the policies for collecting and providing spatial data to the public. There is also no decree related to the work team for spatial data infrastructure handling. Human resources are limited and only available in the Disaster Management Operations Control Center (PUSDALOP).

Hardware infrastructure such as servers and computers and software are available, but data accessibility for the public is still minimal and it does not include volcanic mudflow hazards specifically. The only disaster spatial data produced by BPBD that can be accessed publicly are on the website http://sikk. bpbdmagelang.id/. Figure 2 shows that the portal is mainly related to general disaster hazards in Magelang Regency.

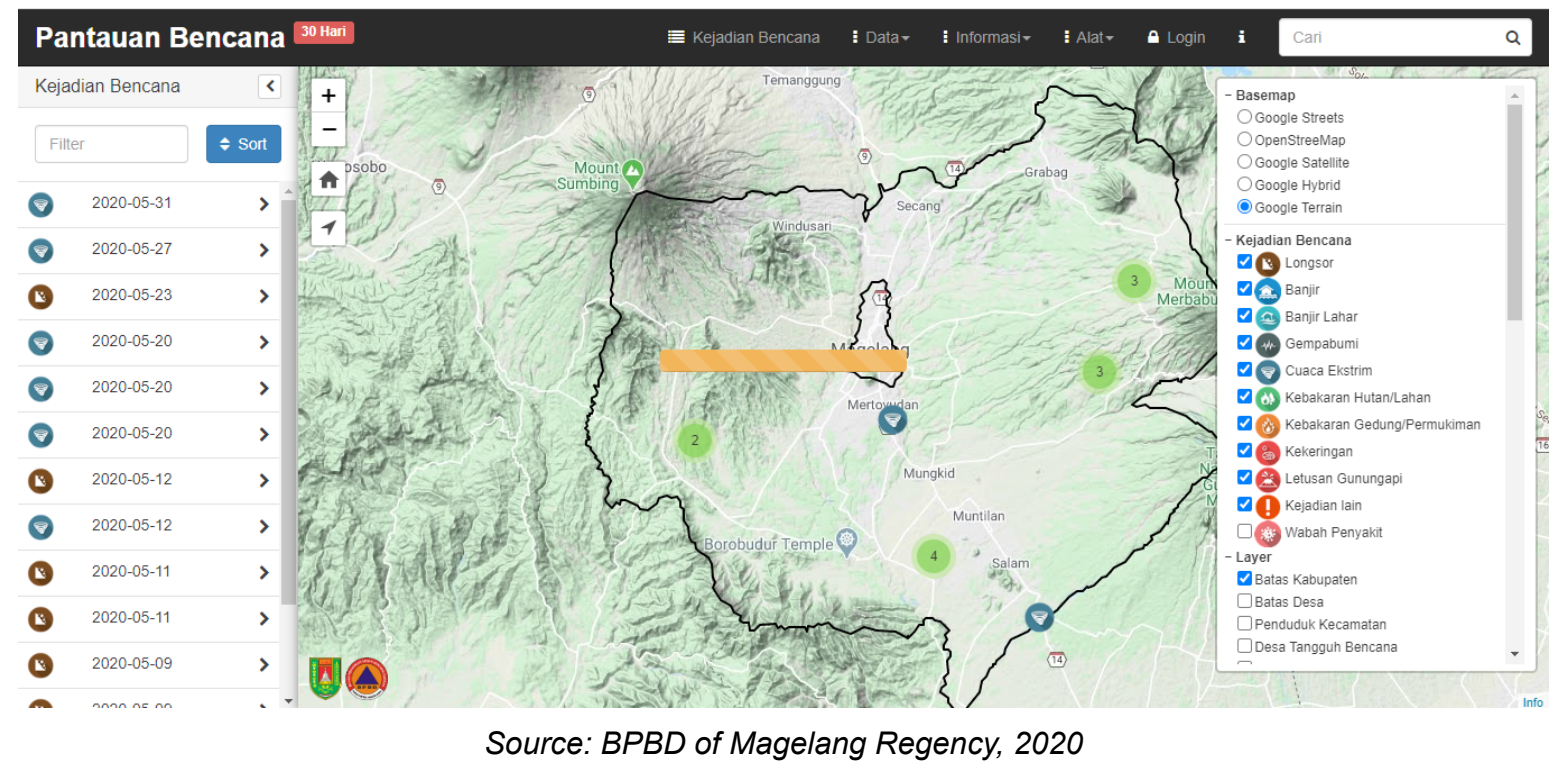

Figure 2. Frontend of BPBD WebGIS.

Table 5. Spatial Data Availability in Magelang Regency

\begin{tabular}{lllccc}
\hline \multicolumn{1}{c}{ Theme } & \multicolumn{1}{c}{ Data } & Data Type & Shape & Coordinates & Metadata \\
\hline $\begin{array}{l}\text { Hydrology/ } \\
\text { Water }\end{array}$ & Putih River & ESRI Shapefile & Vector - Line & UTM & No \\
$\begin{array}{l}\text { Transportation } \\
\text { Facilities }\end{array}$ & Evacuation Route & ESRI Shapefile & Vector - Line & UTM & No \\
& Shelter & ESRI Shapefile & Vector - Point & UTM & No \\
& Heath Facilities & ESRI Shapefile & Vector - Point & UTM & No \\
& Government Office & ESRI Shapefile & Vector - Point & UTM & No \\
\hline
\end{tabular}


Table 6. Condition of Data from BPBD of Magelang Regency

\begin{tabular}{|c|c|c|c|c|}
\hline No & Data & Field & Field Type & Explanation \\
\hline 1 & Putih River & RIVER_NAME & String & Name of the river \\
\hline \multirow[t]{2}{*}{2} & \multirow{2}{*}{$\begin{array}{l}\text { Evacuation } \\
\text { Route }\end{array}$} & WIDTH & String & Width of road \\
\hline & & SOURCE & String & $\begin{array}{l}\text { Road classification (National road, } \\
\text { Provincial Road, District Road, Local } \\
\text { Road) }\end{array}$ \\
\hline \multirow[t]{3}{*}{3} & \multirow[t]{3}{*}{ Shelter } & NAME & String & Name of the shelter \\
\hline & & TYPE & String & $\begin{array}{l}\text { Shelter type (temporary, permanent, } \\
\text { gathering point) }\end{array}$ \\
\hline & & CAPACITY & Integer & Shelter capacity (no data) \\
\hline \multirow[t]{7}{*}{4} & \multirow{7}{*}{$\begin{array}{l}\text { Heath } \\
\text { Facilities }\end{array}$} & HOSPITAL_I & Integer & Hospital identification number \\
\hline & & NAME & String & Hospital name \\
\hline & & CAPACITY & String & Hospital capacity (no data) \\
\hline & & ADDRESS & String & Hospital address \\
\hline & & TEL & String & Telephone number \\
\hline & & AVG_COST & Integer & Cost of treatment \\
\hline & & VILLAGE_ID & Integer & $\begin{array}{l}\text { Village identification number where } \\
\text { the hospital is located }\end{array}$ \\
\hline
\end{tabular}

Table 7. Profile of SDI in Magelang Regency.

\begin{tabular}{|c|c|c|}
\hline No & SDI category & Profile \\
\hline 2 & Access & Limited access. \\
\hline 3 & Standards & Standards follow the Geospatial Information Agency (BIG) of the Republic of Indonesia. \\
\hline 5 & Human Resources & $\begin{array}{l}\text { Limited human resources capable of running GIS and understanding the implementation of } \\
\text { SDI. }\end{array}$ \\
\hline
\end{tabular}

The attribute for the volcanic mudflowrelated data is inadequate and there is a lack of information for both the public and users. The attribute data that are adequate are the health facility data, which include information about the capacity and addresses of hospitals surrounding Putih River. However, data on evacuation routes only contain road width and road type. The shelter data include information about shelter type (temporary or permanent, and gathering point), but there are no data about the capacity and facilities of the shelters. With regard to government office data, these only comprise village office data, with no information related to facilities or other supporting information. Without metadata, it is difficult to trace the complete information, including that related to the attribute. Table 5 shows the spatial data availability from the BPBD of Magelang Regency, while Table 6 shows the condition of attribute data. Table 7 summarises the profile of SDI in Magelang Regency.

\subsection{Prototype of a Volcanic Mudflow Mitigation Geoportal}

A geoportal prototype was built to allow access by government officers and the community to search, discover and visualise geospatial data related to volcanic mudflow and to increase the readiness of local governments to Magelang Regency to develop an SDI. The prototype was built using two types of software, namely server and client 
software. Server software is used to build and run systems, while client software is used by those who use them. Server software includes PHP 7 as a server-side script programming language designed for web development, Apache web server to create content to manage websites and Linux Ubuntu 16 as an operating system that is compatible with various applications. On the other hand, to open the system clients simply use a web browser such as Mozilla Firefox or Google Chrome both on a mobile device (smartphone, tab), laptop or personal computer. The database system built is a responsive system that is easy to open and run on any platform. The minimum hardware specifications are the Intel (R) Xeon (R) CPU E5-2650L v4 @ 1.70GHz, one core with at least 1 GB RAM and a 20 GB hard drive.

TheSpatial DataInfrastructure(SDI) design as a volcanic mudflow mitigation platform was built using an open source platform, a basemap from OpenStreet Map and library from LeafletJS. The geoportal system workflow and the way entities in the system interact, begin when the user logs in. Logging onto the system will call up OpenStreetmap along with thematic data, namely evacuation routes, Putih River, shelter locations, evacuation routes, health facilities and government offices. The user can then access the map online together with the features available on the system. The system workflow is shown as a sequence diagram in Figure 3.

The volcanic mudflow mitigation geoportal in Putih River, Magelang Regency is a user friendly front-end containing header, titles, legends, navigation (zoom in, zoom out), information of attributes and downloadable spatial data. The data included in the system are shelter locations, health facility locations, government office locations, and evacuation routes. Each location is connected to an evacuation route, making it easier for users to understand the evacuation process and nearest health facilities, government office or shelter. In the SDI context, spatial data and information can be used for sharing and conducting other analysis. Geoportals are able to provide users, the community and local government with access to download the data and conduct such analysis. Figure 4 shows the main view of the system.

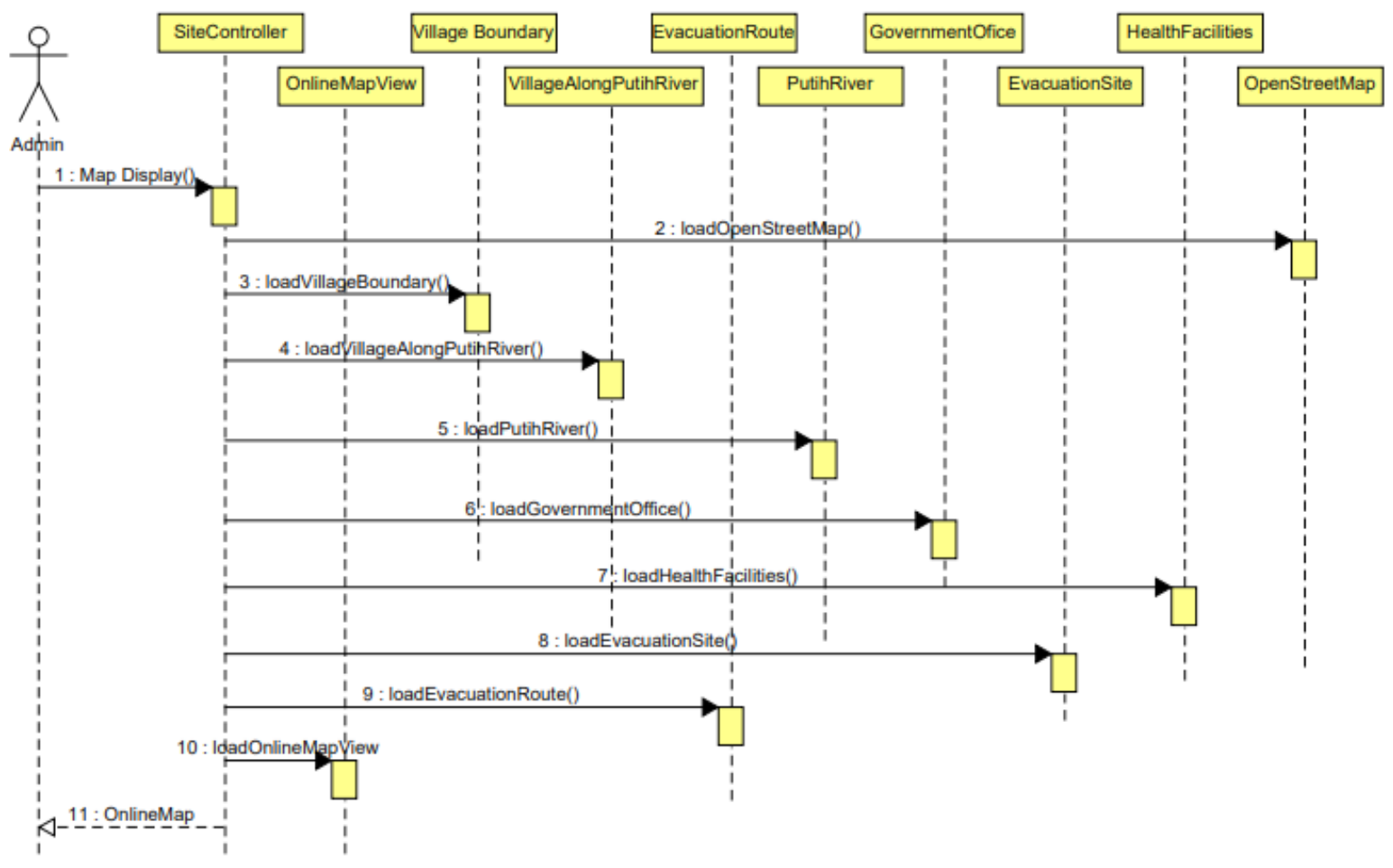

Figure 3. Sequence Diagram of the System Workflow. 

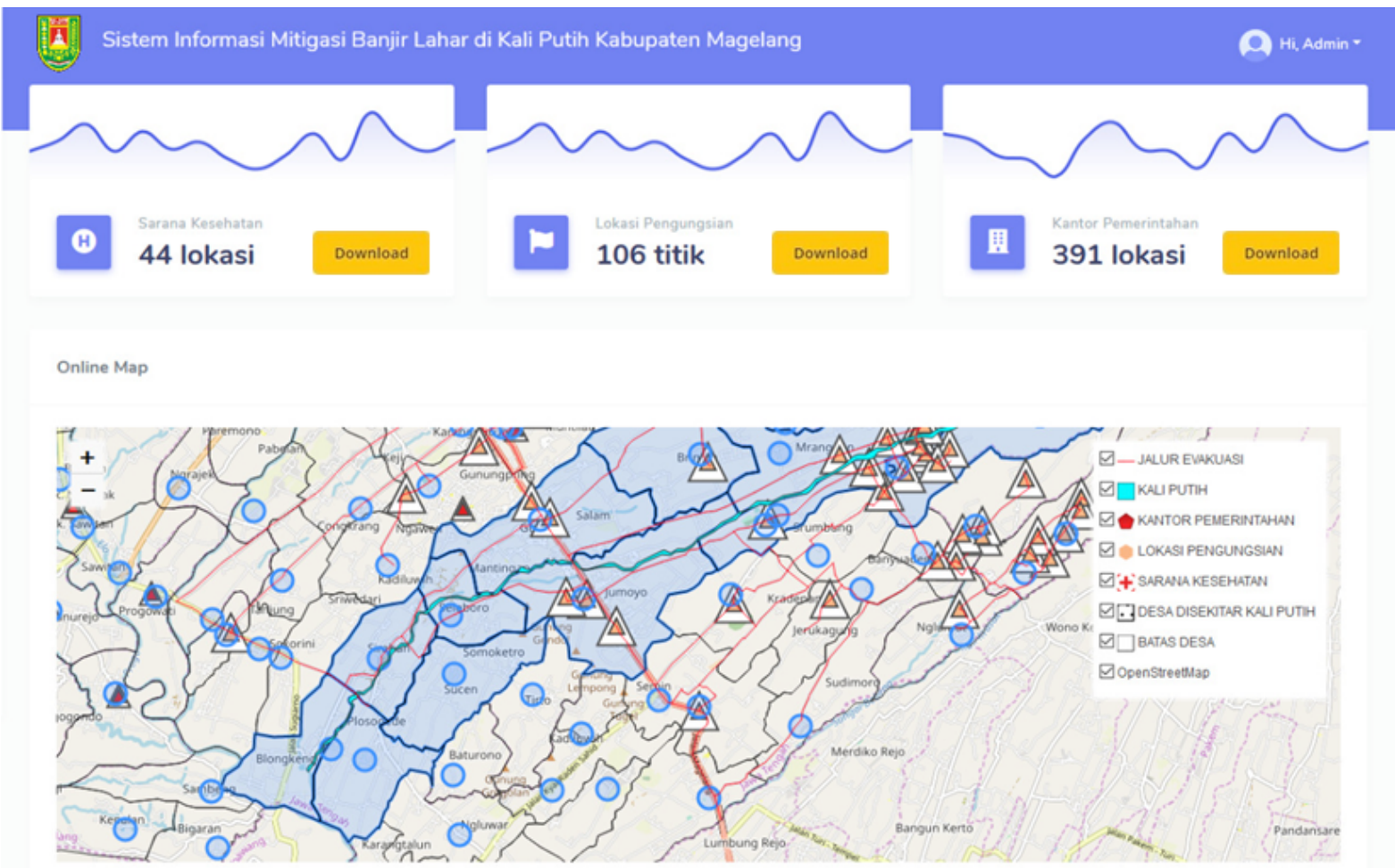

Figure 4. Main View of the System.

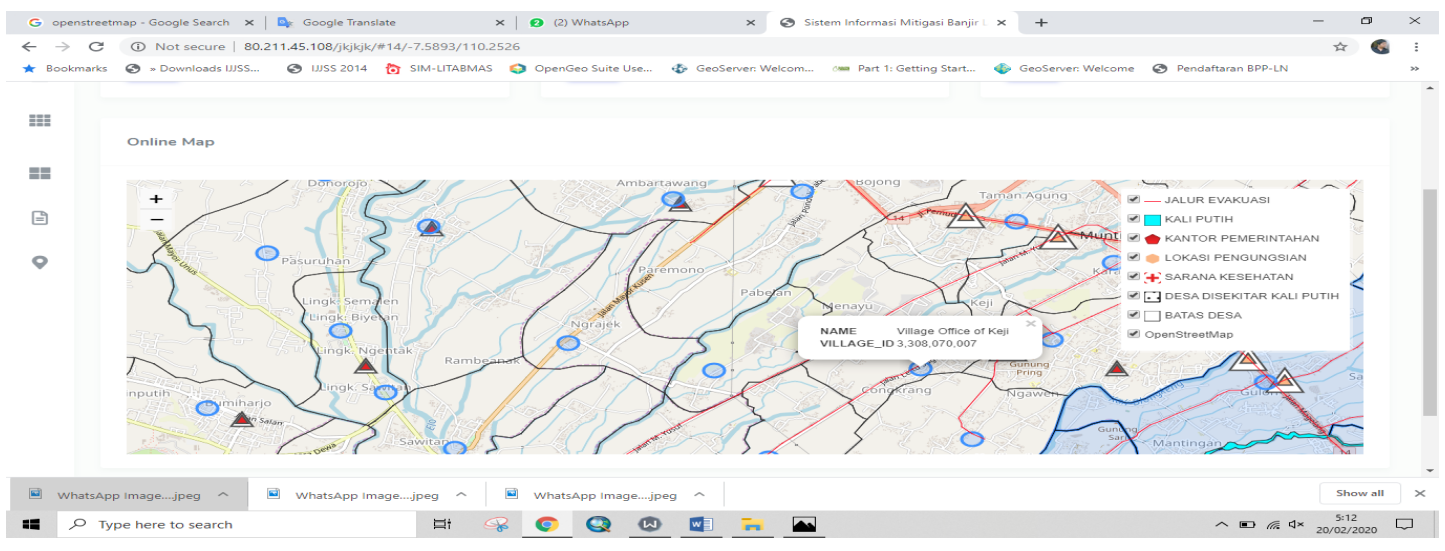

Figure 5. Identification Features.

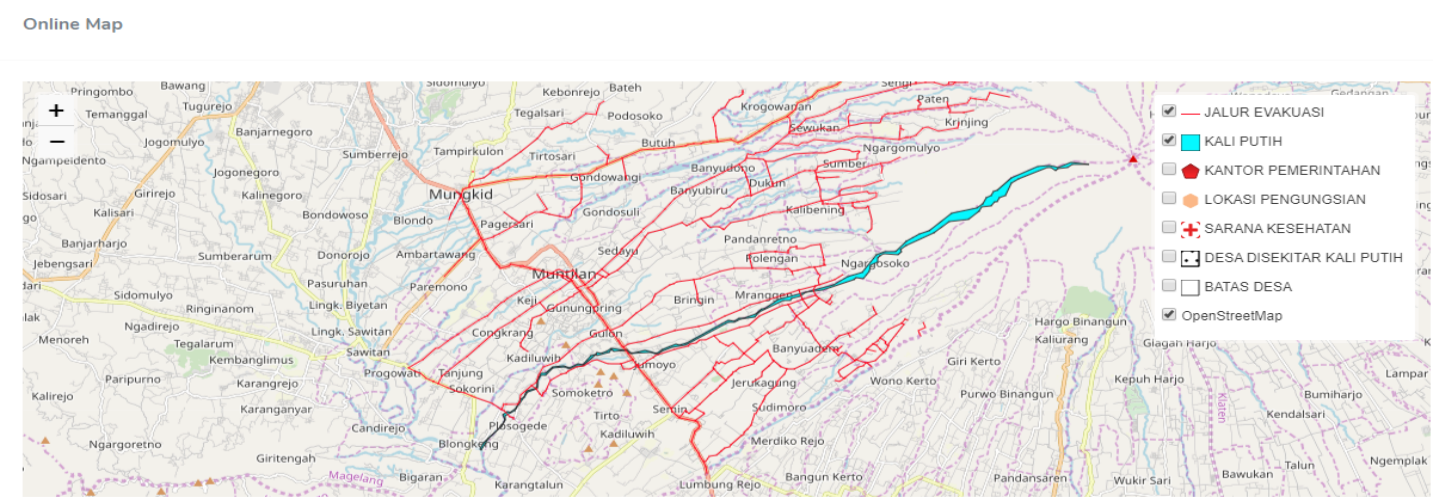

Figure 6. Adjustable Content through the Map Legend. 
All data attribute information can be identified with one click on the data icon. This identification feature allows users to understand the information contained in the data. With the available features, the system can be easily used and it provides sufficient information related to the location that must be addressed when a volcanic mudflow disaster occurs. Figure 5 shows the identification features of the system, which also has a map legend to suit user needs. Users can activate and deactivate one or more items in the legend, such as evacuation routes or evacuation points, so that what is seen on the system can be adjusted. Figure 6 shows the map content in the system through a map legend.

\subsection{System Testing}

Respondents were asked to answer questions after completing the tasks related to system usage shown in Tables 2 and 3. System testing aimed to show the level of usability according to user acceptance in the human computer interface design (Mahyavanshi et al., 2017). The testing results were based on respondents' scores on the questions shown in Figure 7.

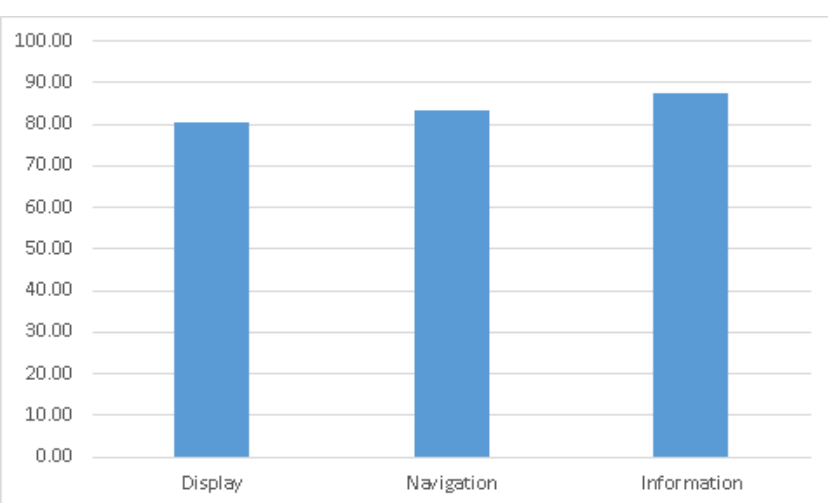

Figure 7. Usability System Testing Score.

For all 10 questions, respondents mainly received scores of between 3 and 5 with total score per respondent range in-between 33 to 45 . Total score was 782 with average of 78.2 which shows satisfaction with using the system. The questions were divided into three categories, display, navigation and information. The average score for three categories were 83.75. Based on the usability testing result of $78.2 \%$ and average score for three questions categories, it can be concluded that the geoportal system functions properly and as expected.

\section{Conclusion}

Magelang Regency government is not fully prepared for implementation of a Spatial Data Infrastructure to support volcanic mudflow mitigation. Overall, the only disaster spatial data possessed by Regional Disaster Mitigation Agency (BPBD) of Magelang Regency that can be accessed publicly is mainly related to disaster hazards in general and not specifically volcanic mudflow hazard mitigation. The available data related to volcanic mudflow mitigation are Putih River channel data, evacuation routes, shelter locations and health facilities. Data availability is relatively complete, but overall metadata is missing and there is a lack of information on attributes.

The development of a geoportal prototype of the volcanic mudflow mitigation information system in Putih River can assist local governments and the community in determining evacuation routes, shelter locations, health facilities and government office locations, all of which can be used as reference for volcanic mudflow mitigation. Based on the usability testing result of $78.2 \%$, it can be concluded that the geoportal system functions fine and proper.

\section{Acknowledgements}

The writers would like to thank Amikom University for the provision of research funds, and the Disaster Management Agency (BPBD) of Magelang Regency and the Serayu Opak River Area Agency (BBWS Serayu Opak) for data. 


\section{References}

Batuk, F., Şengezer, B., \& Emem, O. (2008). Relations between disaster management, urban planning and NSDI. Int. Arch. Photogramm. Remote Sens. Spat. Inf. Sci, 37, 441-444.

Bignami, C., Ruch, J., Chini, M., Neri, M., Buongiorno, M. F., Hidayati, S., \& Sayudi, D. S. (2013). Pyroclastic density current volume estimation after the 2010 Merapi volcano eruption using X-band SAR. Journal of Volcanology and Geothermal Research, 261, 236-243.

Capra, L., Coviello, V., Borselli, L., Márquez-Ramírez, V. H., \& Arámbula-Mendoza, R. (2018). Hydrological control of large hurricane-induced lahars: evidence from rainfall-runoff modeling, seismic and video monitoring. Natural Hazards E Earth System Sciences, 18(3).

De Bélizal, E., Lavigne, F., Hadmoko, D. S., Degeai, J. P., Dipayana, G. A., Mutaqin, B. W., ... \& Vidal, C. (2013). Rain-triggered lahars following the 2010 eruption of Merapi volcano, Indonesia: A major risk. Journal of Volcanology and Geothermal Research, 261, 330-347.

Edler, D., \& Vetter, M. (2019). The simplicity of Modern audiovisual web cartography: an example with the open-source JavaScript Library leaflet. js. KN-Journal of Cartography and Geographic Information, 69(1), 51-62.

Gonda, Y., Hotta, N., Legono, D., \& Santosa, U.B. (2012). Study on Multimodal Sediment Disaster after the 2010 Eruption of Mt. Merapi in Indonesia, Report of A Study on Sabo and Landslide Prevention Technology. Tokyo: Sabo and Landslide Technical Center.

Gonda, Y., Legono, D., Sukatja, B., \& Santosa, U.B. (2014). Debris flows and flash floods in the Putih River after the 2010 eruption of Mt. Merapi, Indonesia. International Journal of Erosion Control Engineering, 7(2), 63-68.

Kotsev, A., Minghini, M., Tomas, R., Cetl, V., \& Lutz, M. (2020). From Spatial Data Infrastructures to Data Spaces - A Technological Perspective on the Evolution of European SDIs. ISPRS International Journal of Geo-Information, 9(3), 176.

Kumar, D., \& Shekhar, S. (2014). Research Prospects in Spatial Data Infrastructure for Handling Energy Linked Disaster's. IOSR Journal of Environmental Science, Toxicology and Food Technology (IOSRJESTFT), 8(5), 53-67.

Kusky, T. M. (2008). Volcanoes: Eruptions and Other Volcanic Hazards. Infobase Publishing.

Kusumawardani, R., Kurniadhi, R., Mukhlisin, M., \& Legono, D. (2017). Rainfall threshold for triggering debris flow on Merapi volcano area, Yogyakarta, Indonesia. In AIP Conference Proceedings (Vol. 1818, No. 1, p. 020027). AIP Publishing LLC.

Lavigne, F., Thouret, J. C., Hadmoko, D. S., \& Sukatja, C. B. (2007). Lahars in Java: Initiations, dynamics, hazard assessment and deposition processes.

Mahyavanshi, N., Patil, M., \& Kulkarni, V. (2017). Enhancing web usability using user behavior and cognitive study. Int. J. Comput. Appl, 164(2), 27.

National Disaster Management Agency (BNPB), Indonesia. (2011). BNPB report released on April 29, 2011. Retrieved 31 May 2020 from: http://www.bnpb.go.id/website/asp/ berita_list.asp?id=434.

Qureshi, M. T., \& Rai, A. (2020). A Four-Pronged Low Cost and Optimized Traffic Routing Solution. International Journal of Interactive Mobile Technologies, 14(10).

Sanger, A. S., \& Nurpatria, N. I. (2018). Comparing Men's and Women's Psychological Preparedness in Cangkringan for Mount Merapi Volcanic Eruptions. KnE Life Sciences, 311-318.

Sterlacchini, S., Bordogna, G., Cappellini, G., \& Voltolina, D. (2018). SIRENE: a spatial data in- 
frastructure to enhance communities' resilience to disaster-related emergency. International Journal of Disaster Risk Science, 9(1), 129-142.

Surono, Jousset, P., Pallister, J., Boichu, M., Buongiorno, M. F., Budisantoso, A., Costa, F., ... \& Humaida, H. (2012). The 2010 explosive eruption of Java's Merapi volcano-a '100-year' event. Journal of volcanology and geothermal research, 241, 121-135.

Swaid, S. I., \& Suid, T. Z. (2018). Usability Heuristics for M-Commerce Apps. In International Conference on Applied Human Factors and Ergonomics (pp. 79-88). Springer, Cham.

Tomas, R., Harrison, M., Barredo, J. I., Thomas, F., Isidro, M. L., Pfeiffer, M., \& Čerba, O. (2015). Towards a cross-domain interoperable framework for natural hazards and disaster risk reduction information. Natural Hazards, 78(3), 1545-1563.

Tripathi, A. K., Agrawal, S., \& Gupta, R. D. (2020). Cloud enabled SDI architecture: a review. Earth Science Informatics, 1-21. 